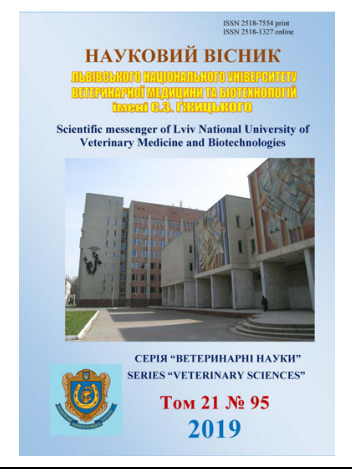

\author{
Науковий вісник Иьвівського національного університету \\ ветеринарної медицини та біотехнологій імені С.3. Гжицького. \\ Серія: Ветеринарні науки \\ Scientific Messenger of Lviv National University \\ of Veterinary Medicine and Biotechnologies. \\ Series: Veterinary sciences
}

\title{
The influence of silicium compounds on the content of calcium, phosphorus and some lipides in the plasma blood
}

\author{
A.I. Ivanitskaya, Ya.V. Lesyk \\ Institute of Animal Biology NAAS, Lviv, Ukraine
}

Article info

Received 04.09.2019

Received in revised form 04.10 .2019

Accepted 05.10.2019

Institute of Animal Biology of NAAS, V. Stusa Str., 38, Lviv, 79000, Ukraine.

Tel.: +38-068-503-46-25

E-mail:lesykyv@gmail.com

Ivanitskaya, A.I., \& Lesyk, Ya.V. (2019). The influence of silicium compounds on the content of calcium, phosphorus and some lipides in the plasma blood. Scientific Messenger of Lviv National University of Veterinary Medicine and Biotechnologies. Series: Veterinary sciences, 21(95), 41-46. doi: $10.32718 /$ nvlvet 9508

The aim of the study was to investigate the effects of nanotechnology and sodium metasilicate on the content of total calcium and inorganic phosphorus and individual lipids in the blood of rabbits from 52 to 110 days of life. Studies were conducted on young rabbits of Hyla breed in the private sector. Rabbits for the study were selected at the age of 41 days on the principle of analogues, weighing 1.2-1.4 kg, were divided into six groups (control and five experimental), 6 animals ( 3 males and 3 females) in each. Animals were kept in with adjustable microclimate and illumination in mesh cages measuring $50 \times 120 \times 30 \mathrm{~cm}$, in accordance with modern animal health standards. The control group rabbits were fed without restriction a balanced granular compound feed, with free access to water. Animals I, II, and III of the study groups were fed a control group diet and fed citrate silicon for 24 hours, with a corresponding rate of 25; 50 and $75 \mu \mathrm{g}$ $\mathrm{Si} / \mathrm{kg}$ body weight. Young animals of the IV and V experimental groups were fed wit diet of the control group and water was given sodium metasilicate $\left(\mathrm{Na}_{2} \mathrm{SiO}_{3} \mathrm{H}_{2} \mathrm{O}\right)$ in the amount of 2.5 and $5.0 \mathrm{mg} \mathrm{Si} / \mathrm{kg}$ body weight, respectively. The experiment lasted 68 days, including the preparatory period of 10 days, the experimental period - 58 days. In the preparatory period - at 52 days and experimental at 83 and 110 days of life ( 31 and 58 days of drinking additives) in 4 animals ( 2 males and 2 females) from the group blood samples were taken for biochemical studies. Studies have found that the concentration of total calcium in the blood plasma of rabbits III and IV study groups was higher by 9.6 and $6.4 \%(P<0.05)$ for 58 days of the study compared with the control, indicating the stimulating effect of the organic compound silicon to activate the processes of assimilation of this macronutrient in the body of young rabbits. Silicone citrate in the large test quantities and sodium metasilicate in the blood plasma of animals of III, IV and V experimental groups respectively increased the level of inorganic phosphorus by 35.7; 28.5 and $35.7 \%(P<0.05)$ than controls at day 58 of the study. In the final study period, the ratio of Calcium to Phosphorus in the animals of the II$V$ experimental groups was in the range of 2.0-1.73: 1, indicating a more pronounced effect of silicon compounds on the metabolism of Phosphorus during a longer period of supplementation. The content of triacylglycerols in the blood plasma of rabbits II and III of the experimental groups was lower $(P<0.05)$ at 31 and 58 days of the study compared with the control. The results obtained may indicate the activation of the processes of metabolic accumulation of plastic components of cell membranes and energy needs of body tissues. The use of silica organic compound reduced the cholesterol content by $37 \%(P<0.05)$ in the blood of rabbits of the III experimental group at 31 days of the study. Whereas at the final stage of the experiment in animals II; In the 3rd and 4th research groups, its level was lower by 43.4; 36.9 and $42.2 \%(P<0.05)$ compared to the control, indicating greater use of cholesterol by the organism with silica organic compound. cate.

Key words: rabbit, calcium, phosphorus, triacylglycerols, cholesterol, silicon citrate, sodium metasili- 


\title{
Вплив сполук силіцію на вміст Кальцію, Фосфору та окремих ліпідів у плазмі крові кролів
}

\author{
А.І. Іваницька, Я.В. Лесик \\ Інститут біологї тварин НААН, м. Львів, Україна
}

\begin{abstract}
Метою дослідження було з'ясувати вплив випоювання цчитрату силіцію, отриманого методом нанотехнології та метасилікату натрію на вміст загального кальцію і неорганічного фосфору та окремих ліпідів у крові кролів у період з 52 до 110 діб життя. Дослідження проводили на молодняку кролів породи Нyla в умовах приватного господарства. Кролів для дослідження відбирали у віці 41 доби за принципом аналогів, масою тіла 1,2-1,4 кг, поділяли на шість груп (контрольну $і$ п'ять дослідних), по 6 тварин (3 самиі і 3 самиці) у кожній. Тварин утримували в приміщеннях із регульованим мікрокліматом та освітленням у сітчастих клітках розміром $50 \times 120 \times 30$ см, відповідно до сучасних ветеринарно-санітарних норм. Кролям контрольної групи згодовували без обмеження збалансований гранульований комбікорм, з вільним доступом до води. Тваринам I, II і III дослідних груп згодовували корми раціону контрольної групи і впродовж доби випоювали наносиліцію циттрат, із розрахунку відповідно 25 ; 50 i 75 мкг Si/кг маси тіла. Молодняку IV i Vдослідних груп згодовували корми раціону контрольної групи $i$ з водою задавали метасилікат натрію ( $\mathrm{Na}_{2} \mathrm{SiO}_{3} \mathrm{H}_{2} \mathrm{O}$ ) в кількості відповідно 2,5 і 5,0 мг Si/кг маси тіла. Дослід тривав 68 діб, в тому числі підготовчий період 10 діб, дослідний - 58 діб. У підготовчому періоді - на 52 добу $і$ дослідному на 83 та 110 доби життя (31 та 58 доби випоювання добавок) у 4 тварин (2 самиі і 2 самиці) з групи відбирали зразки крові для біохімічних досліджень. Дослідженнями встановлено, ицо концентрація загального Кальцію у плазмі крові кролів III і IV дослідних груп була вищою на 9,6 $і$ 6,4\% (P < 0,05) на 58 добу дослідження порівняно з контролем, щз свідчить про стимулювальний вплив органічної сполуки силіцію на активацію процесів засвоєння иьього макроелементу в організмі молодняку кролів. Випоювання тваринам III, IV i V дослідних груп циитрату силіцію у більиих досліджуваних кількостях та метасилікату натрію у плазмі крові відповідно підвищило рівень неорганічного фосфору на 35,7; 28,5 i 35,7\% $(P<0,05)$, ніж у контролі на 58 добу дослідження. На завершальному періоді дослідження співвідношення між Кальцієм і Фосфором у тварин II-V дослідних груп було у межах 2,0-1,73:1, щуо свідчить про більи виражений вплив сполук силіцію на метаболізм Фосфору впродовж тривалішого періоду випоювання добавок. Вміст триацилглічеролів у плазмі крові кролів II і ІІІ дослідних груп був нижчим $(P<0,05)$ на 31 і 58 доби дослідження порівняно з контролем. Отримані результати можуть свідчити про активацію процесів метаболічного нагромадження пластичних компонентів клітинних мембран та енергетичних потреб тканин організму. Застосування органічної сполуки силіцію сприяло зменшенню вмісту холестиролу на 37\% $(P<0,05)$ у крові кролів ІІІ дослідної групи на 31 добу дослідження, тимчасом як на завершальному етапі експерименту у тварин II; III $і$ IV дослідних груп його рівень був відповідно нижчим на 43,4; 36,9 і 42,2\% (P < 0,05) порівняно з контролем, ш⿻ свідчить про більще використання організмом кролів холестеролу за дї органічної сполуки силічію.
\end{abstract}

Ключові слова: кролі, Кальц̧ій, Фосфор, триацилгліцеероли, холестерол, цчитрат силіцію, метасилікат натрію.

\section{Вступ}

Кальцій і Фосфор є основними компонентами кісткової тканини і становлять 65-70\% від усіх мінеральних речовин організму кролів. Кальцій має високу біологічну активність, виконує в організмі різноманітні функції (De Blas \& Wiseman, 2010). Катіони $\mathrm{Ca}^{2+}$, що входять до складу плазми крові і тканинних рідин, підтримують іонну рівновагу, осмотичний тиск у рідинах організму, регуляцію серцевих скорочень, згортання крові (Bas et al., 2005). Фосфор бере участь у енергетичному обміні (Gutierrez et al., 2000). В організмі кролів Кальцій поглинається повністю з раціону, незалежно від метаболічної потреби, а виділення проходить через нирки (Redrobe, 2002). Підтримання в організмі фізіологічного співвідношення Кальцію i Силіцію має велике значення для збереження мінерального гомеостазу. Якщо Силіцію недостатньо, Кальцій його заміщає. В організмі Силіцій бере участь у виробленні колагену, що забезпечує еластичність тканин, Кальцій підтримує міцність кісток. За нестачі Силіцію відбувається кальцинація тканин - вони втрачають пружність та еластичність (Jugdaohsingh et al., 2015).

Обмін Кальцію в організмі кролів пов'язаний із обміном Фосфору, тому важливо, щоб співвідношення цих елементів у раціоні в періоди росту, відтворення та лактації було фізіологічно обгрунтованим.
Особливо необхідно підтримувати оптимальне співвідношення Кальцію і Фосфору в раціоні молодняку кролів для нормального формування кісткової тканини (Marounek et al., 2003). Чим молодша тварина, тим інтенсивніше в іiі організмі відбувається відкладення Кальцію і Фосфору.

Відомо, що Силіцій в оптимальних кількостях у крові $є$ головним елементом зв'язку між всіма макроi мікроелементами організму. Силіцій прискорює процеси формування кістяка, причому сприяє формуванню кісткової тканини, незалежно від вмісту вітаміну Д. Активує ріст і розвиток тварин, бере участь у нормальному обміні ліпідів, вуглеводів та вітамінів (Jugdaohsingh, 2007). Попри широке поширення Силіцію у природі, його засвоюваність в організмі становить близько 4\% від загальної кількості, що надходить у травний канал (Powell et al., 2005). Тому значний науковий інтерес становлять органічні комплекси силіцію (Harkness et al., 2010). Результати проведених досліджень свідчать про можливість застосування у тваринництві цитратних сполук мікроелементів, виготовлених методом нанотехнології (Afolabi et al., 2010). За сучасними поглядами органічні сполуки на основі наночастинок мікроелементів мають своєрідні властивості порівняно 3 їхніми солями мінеральних кислот, регулюють обмінні процеси в клітинах за принципом дії наномеханізмів (Harkness et al., 2013). Тому метою дослідження було дослідити вплив ви- 
поювання цитрату силіцію, отриманого методом нанотехнології, та метасилікату натрію на вміст загального кальцію і неорганічного фосфору та окремих ліпідів у крові кролів у період відгодівлі 352 до 110 доби життя.

\section{Матеріал і методи досліджень}

Дослідження проводили на молодняку кролів породи Hyla в умовах приватного господарства. Кролів для дослідження відбирали у віці 41 доби за принципом аналогії, масою тіла 1,2-1,4 кг, поділяли на шість груп (контрольну і п'ять дослідних), по 6 тварин (3 самці та 3 самиці) у кожній. Тварин утримували в приміщеннях із регульованим мікрокліматом та осві-

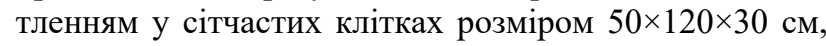
відповідно до сучасних ветеринарно-санітарних норм (Chudley \& Greeno, 2010). Кролям контрольної групи згодовували без обмеження збалансований гранульований комбікорм, з вільним доступом до води. Тваринам I, II і III дослідних груп згодовували корми раціону контрольної групи і впродовж доби випоювали наносиліцію цитрат, із розрахунку відповідно 25; 50 і 75 мкг $\mathrm{Si} /$ кг маси тіла. Розчин наносиліцію цитрату $(0,5$ г/дм³ $\mathrm{pH} 1,35)$ отримано від ТОВ “Наноматеріали і нанотехнології, м. Київ (Kosinov \& Kaplunenko, 2009). Молодняку IV i V дослідних груп згодовували корми раціону контрольної групи і з водою задавали метасилікат натрію $\left(\mathrm{Na}_{2} \mathrm{SiO}_{3} \mathrm{H}_{2} \mathrm{O}\right)$ в кількості відповідно 2,5 і 5,0 мг Si/кг маси тіла. Дослід тривав 68 діб, в тому числі підготовчий період 10 діб, дослідний 58 діб. У підготовчому періоді на 52 добу і дослідному на 83 та 110 добу життя (31 та 58 діб) випоювання добавок) у 4 тварин (2 самці й 2 самиці) з групи відбирали зразки крові у стерильний шприц проколом із крайової вушної вени одноразовою голкою. Місце відбору крові було оброблено спиртом та олійним розчином “Димексиду” (АТ “Галичфарм”) для місцевої гіперемії. Кров для біохімічних досліджень відбирали в пробірки, що містили 1\% гепарин як антикоагулянт. Після отримання крові її відразу ж центрифугували (3000 об/хв) та провели лабораторні дослідження. У плазмі крові визначили: загальний кальцій, неорганічний фосфор, концентрацію триацилгліцеролів та холестеролу колориметричним методом на автоматичному біохімічному аналізаторі ("Roche", Німеччина. Дослідження проводили 3 дотриманням загальноприйнятих біоетичних норм міжнародних положень стосовно проведення експериментальних робіт із хребетними тваринами (Official Journal of the European Union). Цифрові дані опрацьовували статистично з використанням t критерію Стьюдента. Розраховували середні арифметичні величини (М) та похибки середніх арифметичних величин $( \pm \mathrm{m})$. Зміни вважали вірогідними за $\mathrm{P}<0,05$. Для розрахунків використано комп'ютерну програму Excel.

\section{Результати та їх обговорення}

Випоювання кролям різної кількості органічної та неорганічної сполук силіцію впродовж дослідження відзначилося змінами рівня Кальцію і Фосфору в плазмі крові тварин дослідних груп порівняно з контрольною, які залежно від сполуки та їхньої кількості були в межах верхніх або нижніх фізіологічних величин (табл. 1).

\section{Таблиця 1}

Концентрація Кальцію і Фосфору в крові кролів за випоювання силіцію цитрату та метасилікату натрію, $(\mathrm{M} \pm \mathrm{m}, \mathrm{n}=4)$

\begin{tabular}{|c|c|c|c|c|}
\hline \multirow{3}{*}{ Показник } & \multirow{3}{*}{ Група } & \multicolumn{3}{|c|}{ Періоди дослідження } \\
\hline & & \multirow{2}{*}{$\begin{array}{l}\text { Підготовчий } \\
52 \text { доба життя }\end{array}$} & \multicolumn{2}{|c|}{ Дослідний (вік/період випоювання добавок, доба) } \\
\hline & & & $83 / 31$ & $110 / 58$ \\
\hline \multirow{6}{*}{$\begin{array}{c}\text { Загальний Кальцій, } \\
\text { ммоль/л }\end{array}$} & $\mathrm{K}$ & $3,2 \pm 0,10$ & $3,5 \pm 0,15$ & $3,1 \pm 0,05$ \\
\hline & Д-I & $3,4 \pm 0,12$ & $3,6 \pm 0,21$ & $3,3 \pm 0,12$ \\
\hline & Д-II & $3,4 \pm 0,09$ & $3,7 \pm 0,27$ & $3,2 \pm 0,11$ \\
\hline & Д-ІІІ & $3,3 \pm 0,06$ & $3,7 \pm 0,06$ & $3,4 \pm 0,10^{*}$ \\
\hline & Д-IV & $3,5 \pm 0,08$ & $3,8 \pm 0,17$ & $3,3 \pm 0,06^{*}$ \\
\hline & Д-V & $3,5 \pm 0,07$ & $3,7 \pm 0,18$ & $3,3 \pm 0,13$ \\
\hline \multirow{6}{*}{$\begin{array}{c}\text { Неорганічний Фосфор, } \\
\text { ммоль/л }\end{array}$} & K & $1,5 \pm 0,06$ & $1,3 \pm 0,05$ & $1,4 \pm 0,14$ \\
\hline & Д-І & $1,6 \pm 0,14$ & $1,3 \pm 0,17$ & $1,6 \pm 0,09$ \\
\hline & Д-ІІ & $1,7 \pm 0,09$ & $1,4 \pm 0,16$ & $1,6 \pm 0,15$ \\
\hline & Д-III & $1,7 \pm 0,06$ & $1,3 \pm 0,09$ & $1,9 \pm 0,06^{*}$ \\
\hline & Д-IV & $1,4 \pm 0,10$ & $1,4 \pm 0,15$ & $1,8 \pm 0,07 *$ \\
\hline & Д-V & $1,5 \pm 0,16$ & $1,4 \pm 0,12$ & $1,9 \pm 0,10^{*}$ \\
\hline \multirow{6}{*}{ Кальцій:Фосфор } & $\mathrm{K}$ & $2,13: 1$ & $2,69: 1$ & $2,21: 1$ \\
\hline & Д-І & $2,12: 1$ & $2,76: 1$ & $2,06: 1$ \\
\hline & Д-ІІ & $2,00: 1$ & $2,64: 1$ & $2,00: 1$ \\
\hline & Д-ІІІ & $1,94: 1$ & $2,84: 1$ & $1,78: 1$ \\
\hline & Д-IV & $2,50: 1$ & $2,71: 1$ & $1,83: 1$ \\
\hline & Д-V & $2,33: 1$ & $2,64: 1$ & $1,73: 1$ \\
\hline
\end{tabular}

Примітка: тут і далі $*$ - $\mathrm{P}<0,05 ; * *-\mathrm{P}<0,01, * * *-\mathrm{P}<0,001$ порівняно 3 контрольною групою 
Зокрема, концентрація загального кальцію у плазмі крові кролів III і IV дослідних груп була вищою на 9,6 і 6,4\% (P < 0,05) на 58 добу дослідження порівняно 3 контролем. 3 літературних джерел відомо, що Силіцій в організмі сприяє засвоєнню Кальцію. Сполуки силіцію під дією соляної кислоти у шлунку кролів перетворюються в доступну для організму ортосиліцієву кислоту, яка легко проникає через клітинну мембрану. Незважаючи на те, що рослинні корми багаті на Силіцій, його біодоступність обмежена через погану розчинність присутніх його сполук (Redrobe, 2002). Очевидно, застосування більших досліджуваних кількостей цитрату силіцію більше вплинуло на процеси активного засвоєння Кальцію з кормів раціону, що позначилося вищим його рівнем у плазмі крові кролів III і IV дослідних груп.

Аналогічну закономірність встановлено і за вмістом Фосфору. Характерним $є$ його більший вміст на завершальному періоді експерименту, зокрема рівень неорганічного фосфору в плазмі крові тварин III, IV i $\mathrm{V}$ дослідних груп був відповідно вищим на 35,7; 28,5 i $35,7 \%$ (Р < 0,05), ніж у контролі на 58 добу дослідження. Механізми засвоєння Фосфору в організмі кролів повністю не з'ясовані. У більшості видів ссавців неорганічний фосфор всмоктується 3 дванадцятипалої і тонкої кишки й регулюється ендокринною системою (Barlet et al., 1995). Дослідженнями (Sabbagh et al., 2011) з'ясовано існування активного механізму транспорту Фосфору з дванадцятипалої й проксимальної тонкої кишки у 3-місячних кроликів. Цілком імовірно більш активне поглинання Фосфору в молодих тварин, ніж у дорослих (Marounek et al., 2003). Крім метаболізму Фосфору, Силіцій бере участь у підтримці взаєморівноваги з Кальцієм, тому в дослідженні вмісту Кальцію і Фосфору в крові важливим $\epsilon$ їхнє співвідношення. 3 літературних джерел відомо, що оптимальне співвідношення Кальцію до
Фосфору повинно бути в межах 1,5-2:1 (Vandelli, 1995; Mehrotra et al., 2006). Аналіз таблиці 1 свідчить, що на 31 добу випоювання сполук силіцію спостерігали співвідношення Кальцію до Фосфору у межах 2,64-2,84:1, що свідчить про активуючий вплив органічних сполук силіцію на метаболізм Кальцію в організмі кролів. Вищий вміст Кальцію порівняно з рекомендаціями є не бажаним, оскільки зменшує засвоюваність Фосфору в організмі кролів. Однак на 58 добу дослідження співвідношення між вказаним елементами у тварин II-V дослідних груп було в межах 2,01,73:1, що свідчить про більш виражений дозозалежний вплив сполук силіцію на метаболізм Фосфору впродовж тривалішого періоду випоювання добавок. 3 літературних джерел (Marounek et al., 2009; ElSagheer \& Hassanein, 2014; Moran et al., 2016) відомо, що потреба мікрофлори кишечнику в деяких мінеральних елементах може бути вищою за потребу організму тварин. Очевидно сполуки силіцію у фізіологічних кількостях створюють оптимальне середовище для життєдіяльності мікрофлори сліпої та товстої кишок кролів, що сприяє їхньому росту, підвищує ферментативну активність, у результаті чого активується перетравність і засвоюваність корму та мінеральних речовин у травному каналі тварин досліджуваних груп.

Силіцій є одним із елементів, що забезпечує нормальний перебіг метаболічних процесів організму, в тому числі задіяний у ліпідному обміні. Зокрема, вміст триацилгліцеролів у плазмі крові кролів II і III дослідних груп був вірогідно нижчим на 31 і 58 добу дослідження порівняно 3 контролем (табл. 2). Отримані результати можуть свідчити про активацію процесів метаболічного нагромадження пластичних компонентів клітинних мембран та енергетичних потреб тканин організму, що було більше виражено за дії органічної сполуки силіцію.

\section{Таблиця 2}

Вміст триацилгліцеролів і холестеролу в крові кролів за випоювання силіцію цитрату та метасилікату натрію, $(\mathrm{M} \pm \mathrm{m}, \mathrm{n}=4)$

\begin{tabular}{|c|c|c|c|c|}
\hline \multirow{3}{*}{ Показник } & \multirow{3}{*}{ Група } & \multicolumn{3}{|c|}{ Періоди дослідження } \\
\hline & & \multirow{2}{*}{$\begin{array}{l}\text { Підготовчий } \\
52 \text { доба життя }\end{array}$} & \multicolumn{2}{|c|}{ Дослідний (вік/період випоювання добавок, доба) } \\
\hline & & & $83 / 31$ & $110 / 58$ \\
\hline \multirow{6}{*}{$\begin{array}{l}\text { Триацилгліцероли, } \\
\text { ммоль/л }\end{array}$} & K & $1,08 \pm 0,11$ & $1,20 \pm 0,11$ & $1,02 \pm 0,13$ \\
\hline & Д-І & $1,06 \pm 0,13$ & $0,92 \pm 0,10$ & $1,03 \pm 0,10$ \\
\hline & Д-II & $1,08 \pm 0,10$ & $0,64 \pm 0,17^{*}$ & $0,57 \pm 0,07^{*}$ \\
\hline & Д-ІІІ & $1,05 \pm 0,11$ & $0,62 \pm 0,17^{*}$ & $0,64 \pm 0,08^{*}$ \\
\hline & Д-IV & $1,11 \pm 0,13$ & $0,91 \pm 0,06$ & $0,68 \pm 0,12$ \\
\hline & Д-V & $1,09 \pm 0,40$ & $0,88 \pm 0,13$ & $0,73 \pm 0,11$ \\
\hline \multirow{6}{*}{ Холестерол, ммоль/л } & K & $3,12 \pm 0,25$ & $3,32 \pm 0,85$ & $3,22 \pm 0,71$ \\
\hline & Д-І & $3,36 \pm 0,39$ & $2,34 \pm 0,29$ & $2,97 \pm 0,34$ \\
\hline & Д-ІІ & $3,12 \pm 0,60$ & $1,41 \pm 1,10$ & $1,40 \pm 0,14^{*}$ \\
\hline & Д-ІІІ & $2,84 \pm 0,27$ & $1,23 \pm 0,02 *$ & $1,19 \pm 0,05^{*}$ \\
\hline & Д-IV & $2,75 \pm 0,21$ & $1,30 \pm 0,05$ & $1,36 \pm 0,11^{*}$ \\
\hline & Д-V & $2,95 \pm 0,08$ & $1,25 \pm 0,10$ & $1,80 \pm 0,22$ \\
\hline
\end{tabular}

За нестачі Силіцію в організмі кролів холестерол не використовується і накопичується в судинах (Özkan et al., 2012). Застосування органічної сполуки силіцію сприяло зменшенню вмісту холестеролу на $37 \%(\mathrm{P}<0,05)$ у крові кролів III дослідної групи на 31 добу дослідження, тимчасом на завершальному етапі 
експерименту в плазмі крові тварин II; III і IV дослідних груп його рівень був відповідно нижчим на 43,4; 36,9 і 42,2\% (P < 0,05) порівняно 3 контролем, що свідчить про більше використання в їхньому організмі холестеролу за дії фізіологічно обгрунтованих кількостей сполук силіцію.

Таким чином, за результатами проведеного дослідження встановлено дозозалежний вплив сполук силіцію на засвоєння загального кальцію і неорганічного фосфору та триацилгліцеролів й холестеролу в організмі молодняку кролів.

\section{Висновки}

1. Випоювання кролям цитрату $\mathrm{Si}$ та метасилікату натрію позначилося у плазмі крові тварин III i IV дослідних груп відповідно вищим на 9,6 i 6,4\% $(\mathrm{P}<0,05)$ вмістом загального кальцію та III, IV i V груп вищим на 35,$7 ; 28,5$ і 35,7\% (P < 0,05) рівнем неорганічного фосфору на 58 добу дослідження порівняно $з$ контролем.

2. Застосування сполук силіцію сприяло зниженню вмісту триацилгліцеролів у плазмі крові кролів II і III дослідних груп впродовж дослідження та зменшенню рівня холестеролу на $37 \%(\mathrm{P}<0,05)$ у ІІІ групі на 31 добу та II; III i IV дослідних груп відповідно його зниженню на 43,4; 36,9 і 42,2\% (P < 0,05) на 58 добу експерименту порівняно з контролем.

3. Результати дослідження вмісту мінеральних речовин та ліпідів у плазмі крові кролів свідчать про активацію процесів метаболізму та енергетичних потреб тканин організму, що було більше виражено за дозозалежного впливу органічної сполуки силіцію впродовж тривалішого періоду випоювання.

\section{References}

Afolabi, K.D., Akinsoyinii, A.O., Olajide, R., \& Akinleye, S.B. (2010). Haematological parameters of the Nigerian local grower chickens fed varying dietary levels of palm kernel cake. Proc. of the $35^{\text {th }}$ Annual Conf. of the Nig. Soc. for Anim. Prod.

Barlet, J.P., Davicco, M.J., \& Coxam, V. (1995). Physiologie de l'absorption intestinale du phosphore chezl'animal. Reproduction Nutrition Development, 35(5), 475-489. doi: 10.1051/rnd:19950502.

Bas, S., Bas, A., Lopez, I., Estepa, J.C., Rodriguez, M., \& Aguilera-Tejero, E. (2005). Nutritional secondary hyperparathyroidism in rabbits. Domestic Animal Endocrinology, 28(4), 380-390. doi: 10.1016/ j.domaniend.2005.01.002.

Chudley, R., \& Greeno, R. (2010). Building Construction Handbook. $\quad 8^{\text {th }} \quad$ ed. Elsevier Ltd. https://trove.nla.gov.au/work/7941755.

De Blas, C., \& Wiseman, J. (2010). Nutrition of the Rabbit. $2^{\text {nd }}$ Edition. Library of Congress Cataloging-inPublication Data. http://wabbitwiki.com/images/7/7d/ Nutrition.of.the.Rabbit.2ed-deBlas. Wiseman.pdf.

El-Sagheer, M., \& Hassanein, H.M. (2014). Effect of enzymes and probiotic mixture supplementation to the diet on performance and carcass criteria of growing females of three rabbits strains. Egypt. Poult., 34(1), 273-278. doi: 10.21608/EPSJ.2014.5316.

Gutierrez, I., Garcia, J., Carabano, R., Mateos, G.G., \& de Blas, J.C. (2000). Effect of exogenous phytase on phosphorus and nitrogen digestibility in growingfinishing rabbits. In: Blasco A. (ed.) Proceedings of $7^{\text {th }}$ World Rabbit Congress, Valencia. Valencia University Publications, Valencia.

Harkness, J.E., Turner, P.V., VandeWoude, S., \& Wheler, C.L. (2010). Harkness and Wagner's biology and medicine of rabbits and rodents. $5^{\text {th }}$ ed. Ames, Chester, Wiley-Blackwell, American College of Laboratory Animal Medicine.

Harkness, J.E., Turner, P.V., VandeWoude, S., \& Wheler, C.L. (2013). Haematology, clinical chemistry, and urinalysis. In: Biology and medicine of rabbits and rodents. $5^{\text {th }}$ ed. Ames, IA, Wiley, 116-131.

Jugdaohsingh, R. (2007). Silicon and bone health. J. Nutr. Health. Aging, 11(2), 99-110. https://www.ncbi.nlm.nih.gov/pubmed/17435952.

Jugdaohsingh, R., Kessler, K., Messner, B., Stoiber, M., Pedro, L.D, Schima, H., Laufer, G., Powell, J.J., \& Bernhard, D. (2015). Dietary Silicon Deficiency Does Not Exacerbate Diet-Induced Fatty Lesions in Female ApoE Knockout Mice. The Journal of Nutrition, 145(7), 1498-1506. doi: 10.3945/jn.114.206193.

Kosinov, M.V., \& Kaplunenko, V.G. (2009). Patent of Ukraine for Utility Model No. 38391. IPC (2006): C07C 51/41, C07F 5/00, C07F 15/00, C07C 53/126 (2008.01), C07C 53/10 (2008.01), A23L 1/00, B82B $3 / 00$. Method of obtaining metal carboxylates. Nanotechnology for the production of metal carboxylates. Publ. Jan 12, 2009 Bull No. 1/2009.

Marounek, M., Brenova, N., Suchorska, O., \& Mrazek, J. (2009). Phytase activity in rabbit caecal bacteria. Folia Microbiologica, 54(2), 111-114. doi: 10.1007/s12223009-0016-7.

Marounek, M., Duskova, D., \& Skrivanova, V. (2003). Hydrolysis of phytic acid and its availability in rabbits. British Journal of Nutrition, 89(3), 287-294. doi: 10.1079/BJN2002785.

Mehrotra, M., Gupta, S.K., Kumar, K., Awasthi, P.K., Pandey, C.M., \& Godbole, M.M. (2006). Calcium deficiency-induced secondary hyperparathyroidism and osteopenia are rapidly reversible with calcium supplementation in growing rabbit pups. British Journal of Nutrition, 95(3), 582-590. doi: 10.1079/ BJN20051656.

Moran, K., Lange, C.F.,.Ferket, P., Fellner, V., Wilcock, P., \& Heugten, E. (2016). Enzyme supplementation to improve the nutritional value of fibrous feed ingredients in swine diets fed in dry or liquid form. J. Anim. Sci., 94(3), 1031-1040. doi: 10.2527/jas.2015-9855.

Official Journal of the European Union L276/33, 2010. Directive 2010/63/EU of The European Parliament and of The Council of 22 September 2010 on the protection of animals used for scientific purposes. 86/609/EC. 20.10.2010.

Özkan, C., Kaya, A., \& Akgül, Y. (2012). Normal values 
of haematological and some biochemical parameters in serum and urine of New Zealand White rabbits. World Rabbit Sci., 20(4), 253-259. doi: 10.4995/wrs.2012.1229.

Powell, J.J., McNaughton, S.A., Jugdaohsingh, R., Anderson, S.H., Dear, J., Khot, F., Mowatt, L., Gleason, K.L., Sykes, M., Thompson, R.P., Bolton-Smith, C., \& Hodson, M.J. (2005). A provisional database for the silicon content of foods in the United Kingdom. Br. J. Nutr., 94(5), 804-812. doi: 10.1079/BJN20051542.
Redrobe, S. (2002). Calcium metabolism in rabbits. Seminars in Avian and Exotic Pet Medicine, 11(2), 94101. doi: 10.1053/saep.2002.125100.

Sabbagh, Y., Giral, H., Caldas, Y., Levi, M., Schiav, C. (2011). Intestinal Phosphate Transport. Advances in chronic kidney disease,18(2), 85-90. doi: 10.1053/j.ackd.2010.11.004.

Vandelli, A. (1995). Attenti a calico e fosforo. Rivista di Coniglicoltura, 12, 36-47. doi: 10.5897/AJB12.2588. 